\title{
KINERJA DINAS TENAGA KERJA KABUPATEN MELAWI
}

\author{
Jhony Fredy Hahury \\ Fakultas Ilmu Sosial dan Ilmu Politik Universitas Kapuas \\ Alamat : Jl. YC. Oevang Oerang No. 92 Sintang \\ Email :jf28hahury@gmail.com
}

\begin{abstract}
Abstrak :Tujuan Penelitian ini untuk mendeskripsikan tentang kinerja Dinas Tenaga Kerja Kabupaten Melawi. Informan penelitian terdiri dari Kepala Dinas, Sekretaris Dinas, Kepala Sub Bagian Umum dan Kepegawaian, dan pegawai Dinas Tenaga Kerja.Penelitian bersifat deskriptif kualitatif dengan teknik pengumpulan data wawancara, teknik observasi dan dokumentasi. Hasil penelitian menunjukkan bahwakinerja sudah dilaksanakan secara efektif. Hal ini terlihat dengan sikap kerja pegawai yang bekerja secara bertanggung jawab dengan menyelesaikan tugas-tugasnya seperti melayani masyarakat dalam hal mengurus kartu tanda pencari kerja, memberikan informasi dan pelatihan bagi masyarakat pencari kerja.Dengan sikap kerja pegawai yang bertanggung jawab yang dilakukan dapat meningkatkan kinerja Dinas Tenaga Kerja Kabupaten Melawi yang maju dan profesional.
\end{abstract}

Kata Kunci : Kinerja

\section{PENDAHULUAN}

Aparatur sipil negara (ASN) diserahi tugas untuk melaksanakan tugas pelayanan publik, tugas pemerintahan, dan tugas pembangunan tertentu.Tugas pelayanan publik dilakukan dengan memberikan pelayanan kepada masyarakat dalam rangka penyelenggaraan fungsi umum pemerintahan yang meliputi pendayagunaan kelembagaan, kepegawaian, dan ketatalaksanaan.Sumberdaya manusia dalam kaitan dengan hal ini adalah aparatur sipil negara (ASN) yaitu sebagai penggerak roda mekanisme administrasi dalam organisasi pemerintahan. Aparatur sebagai unsur aparatur negara dan abdi masyarakat mempunyai peran penting dalam pembangunan untuk menciptakan masyarakat madani dan dituntut untuk berperan aktif dalam memberikan pelayanan publik yang prima kepada masyarakat.

Undang-Undang Nomor 5 Tahun 2014 tentang Aparatur Sipil Negara (ASN) sebagai bentuk komitmen pemerintah dalam rangka meningkatkan kinerja dan disiplin aparatur sipil negara. Untuk mewujudkan tujuan nasional dan pelaksanaan cita-cita bangsa dibutuhkan pegawai untuk melaksanakan tugas pelayanan publik, tugas pemerintahan, dan tugas pembangunan tertentu, maka perlu dibangun aparatur sipil negara yang memiliki integritas, profesional, netral dan bebas dari intervensi politik, bersih dari praktik korupsi, kolusi, dan nepotisme, serta mampu menyelenggarakan pelayanan publik bagi masyarakat dan mampu menjalankan peran sebagai unsur perekat persatuan dan kesatuan bangsa berdasarkan Pancasila dan Undang-Undang Dasar Negara Republik Indonesia Tahun 1945.

Kompetensi dan kualifikasi yang diperlukan oleh aparatur sipil negara untuk mengelola birokrasi dengan prinsip pemerintahan yang baik dengan semangat visi reformasi birokrasi yang bertanggung jawab. Kewajiban mengelola dan mengembangkan dirinya dan wajib mempertanggungjawabkan kinerjanya dan menerapkan prinsip etika disiplin dalam penyelenggaraan birokrasi pemerintahan.Hakikatnya aparatur sipil merupakan pelaksana kebijakan publik yang berkedudukan sebagai unsur aparatur negara. Selaku pelaksana kebijakan publik, pelayan publik, serta perangkat yang harus memberi contoh dan teladan kepada masyarakat para pegawai wajib memiliki disiplin yang tinggi.Sebagai bagian dari aparatur negara, tanggung jawab setiap aparatur tentunya sangat menunjang kinerja aparatur sipil Negara dalam rangka mewujudkan penyelenggaraan pemerintahanyang dapat berjalan lancar, efektif, dan efisien.

Pendayagunaan aparatur publik pada dasarnya tidak dapat dipisahkan dari sikap kerja pegawai yang bertanggung jawab.Berkaitan dengan hal itu, Dinas Tenaga Kerja Kabupaten Melawisebagai instansi pemerintahan dituntut untuk bekerja dengan profesional sehingga dapat tercapai pelayanan publik yang baik.Dalam melaksanakan tugas tidak terlepas dari dukungan dan kerjasama 
setiap aparatur agar mampu bersinergi serta membentuk sikap keraj aparatur sipil negara yang dilandasi dengan etika, moral yang baik agar mampu bekerja dalam meningkatkan kinerja secara baik.

Berdasarkan beberapa alasan inilah maka penulis tertarik melakukan penelitian dengan judul kinerja Dinas Tenaga Kerja Kabupaten Melawi dengan berfokus kepada sikap kerja pegawai.Dengan perilaku yang didasari dengan etika dan tanggung jawab tentunya pegawai mampu bekerja secara optimal sehingga dapat meningkatkan kinerja dinasTenaga Kerja Kabupaten Melawi.

\section{KAJIAN PUSTAKA}

Kinerja merupakan hasil kerja secara kualitas dan kuantitas yang dicapai oleh seorang pegawai dalam melaksanakan tugasnya sesuai tanggung jawab yang diberikan kepadanya. Kinerja dalam organisasi sebagai jawaban dari berhasil atau tidaknya tujuan organisasi yang telah ditetapkan. Kinerja pemerintah dalam lingkup kajian organisasi adalah secara makro merupakan tujuan, dan citacita, dan harapan suatu organisasi yang diusahakan pencapaiannya dan perwujudannya melalui organisasi tersebut.

Kinerja adalah catatan mengenai akibatakibat yang dihasilkan pada sebuah fungsi pekerjaan atau aktivitas selama periode tertentu yang berhubungan dengan tujuan organisasi.kinerja seseorang merupakan gabungan dari kemampuan, usaha, dan kesempatan yang dapat diukur dari akibat yang dihasilkannya (Umam, 2009:186). Menurut Murphy dan Cleveland dalam Nasucha (2004:107) kinerja dapat diartikan sebagai kualitas perilaku yang berorientasi pada tugas atau pekerjaan.Lebih lanjut menurut Miner dalam Umam (2010:187) mengatakan bahwa kinerja sebagai perluasan dari bertemunya individu dan harapan tentang apa yang seharusnya dilakukan individu terkait dengan suatu peran, dan kinerja tersebut merupakan evaluasi terhadap berbagai kebiasaan dalam organisasi yang membutuhkan standardisasi yang jelas.

Selanjutnya menurut Mangkunegara (2007:67) menyatakan bahwa kinerja berasal dari kata job performance atau actual performance (prestasi kerja atau prestasi sesungguhnya yang dicapai oleh seseorang). Oleh karena itu, kinerja (prestasi kerja) adalah sebagai kesuksesan individu dalam melakukan pekerjaanya. dengandapat dinyatakan bahwa kinerja adalah kemampuan untuk merealisasikan kemampuan kerja pegawai sesuai dengan tugas dan tanggung jawab dari pekerjaan yang diembannya. Dengan demikian, peningkatan kinerja pegawai adalah proses untuk meningaktkan kemampuan kerja, penampilan kerja atau performance kerja seseorang yang dapat dilakukan dengan berbagai cara.

Kinerja merupakan suatu yang lazim digunakan memantau produktivitas kerja sumberdaya manusia, baik yang berorientasi pada produksi barang, jasa maupun pelayanan.demikian pula, perwujudan kinerja yang membanggakan juga sebagai imbalan intrinsik. Hal ini akanterus berlanjut dalam bentuk kinerja berikutnya, dan seterusnya. agar dicapai kinerja yang professional, hal-hal seperti kerelaan, pengembangan diri pribadi, pengembangan kerjasama yang saling menguntungkan, serta partisipasi seutuhnya dikembangkan (Umam, 2010:187).

Oleh karena itu, dengan kinerja aparatur dinas yang baik dalam memberikan pelayanan administrasi kepada masyarakat diharapkan dapat memenuhi harapan masyarakat yang hendak dicapai. Pengembangan terhadap sumberdaya aparatur dinasuntuk meningkatkan kemampuan dan motivasi kerja. Hal ini menunjukkan bahwa kinerja aparatur dinas mempunyai peranan yang penting dalam bekerja. Artinya harus mampu mewujudkan perubahan dengan secara inovatif dan proaktif dalam memberikan pelayanan dengan optimal kepada masyarakat.

Mangkunegara dalam Umam (2010:189) menyatakan bahwa faktor yang mempengaruhi kinerja, yakni : 1) Faktor kemampuan. Secara psikologis, kemampuan (ability) pegawai terdiri atas kemampuan potensi (IQ) dan kemampuan realita (pendidikan). Oleh karena itu, pegawai perlu ditempatkan pada pekerjaan yang sesuai dengan keahliannya. 2) Faktor motivasi. Faktor ini terbentuk dari sikap (attitude) seorang pegawai dalam menghadapi situasi kerja. Motivasi merupakan kondisi yang menggerakan pegawai ke arah pencapaian tujuan kerja. 3) Sikap mental merupakan kondisi mental yang mendorong seseorang untuk berusaha mencapai potensi kerja secara maksimal.

Berdasarkan pendapat di atas, sikap seorang pegawai sangat berpengaruh dalam bekerja.artinya bahwa sikap dan perilaku yang dapat membentuk seseorang dalam melakukan tindakan-tindakan yang rasional bahkan tidak rasional. sebagaimana Gibson (1997) dalam Umam 
(2010:183) menjelaskan sikap sebagai perasaaan positif atau negatif atau kendaan mental yang selalu disiapkan, dipelajari, dan diatur melalui pengalaman yang memberikan pengaruh khusus pada respon seseorang terhadap orang, objek ataupun keadaan. Oleh Aniek (2005) dalam Umam (2010:184) dijelaskan bahwa sikap kerja sebagai kecenderungan pikiran dan perasaan puas atau tidak puas terhadap pekerjaan. Indikasi karyawan (pegawai) yang merasa puas pada pekerjaannya akan bekerja keras, jujur, tidak malas, dan ikut memajukan perusahaan. Sebaliknya karyawan yang tidak puas pada pekerjaannya akan bekerja seenaknya, bekerja kalau ada pengawasan, tidak jujur, yang akhirnya merugikan perusahaannya.

Berdasarkan uraian tersebut, dapat disimpulkan bahwa aspek-aspek yang mendukung sikap kerja antara lain, pemilahan, penataan, pembersihan, pemantapan, dan pembersihan.Tujuannya adalah menciptakan suatu kerja yang sesuai kebiasaan yang baik dan perilaku yang baik sehingga karyawan (pegawai) dapat bekerja dengan lancar dan mematuhi aturan. Sebagai Blum dan Naylor dikutip oleh Aniek (2005) dalam Umam (2010:184-185) berpendapat bahwa faktor yang mempengaruhi sikap kerja, antara lain kondisi kerja, pengawasan atasan, kerjasama dari teman sekerja, keamanan, kesempatan untuk maju, fasilitas kerja, dan gaji.

Dengan sikap kerja yang baik dapat menjadi pegangan bagi pegawai dalam mengubah perilaku pegawai agar bekerja dengan bertanggung jawab demi pencapaian tujuan dan mampu meningkatkan kinerja organisasi secara efektif.Kinerja yang dicapai oleh suatu organisasi pada dasarnya adalah prestasi anggota organisasi itu sendiri.sumberdaya manusia merupakan aset vital pada hampir semua jenis organisasi. Oleh karena itu, upaya memperbaiki kinerja organisasi tidak mungkin dapat berhasil jika perilaku para pegawai tidak diarahkan dengan baik.Sebagaimana Mahsun (2006) dalam Atong (2018:146) menyatakan informasi hasil pengukuran kinerja dapat dijadikan feedback (umpan balik) untuk mengarahkan perilaku pegawai ini untuk menuju perbaikan kinerja selanjutnya.Feedback memuat informasi objektif mengenai kinerja individual dan kolektif merupakan langkah dasar dalam upaya perbaikan kinerja.

Feedback pengukuran kinerja yang diterima oleh seseorang pegawai akan dijadikan intropeksi melihat kelemahan dan kemampuan yang dimiliki. Sehingga dengan penerima mendapat feedback tersebut ada beberapa kemungkinan perubahan perilaku yang bisa muncul.Perubahan perilaku tersebut, oleh Mahsun (2006) dalam Atong (2018:147) dikatakan bahwa, yakni : 1) Pegawai mempunyai keinginan untuk memperbaiki kinerja tetapi tidak memahami apayang harus dilakukan. 2) Pegawai sangat bersemangat di awal periode tetapi selanjutnya kembali pada perilaku yang sebenarnya. 3) Pegawai termotivasi untuk mampu lebih baik daripada kinerja selanjutnya dengan upaya yang tekun terus menerus. 4) Pegawai melakukan perlawanan dan tidak merasa bertanggung jawab untuk perbaikan kinerja berikutnya.

\section{METODE PENELITIAN}

Penelitian ini menggunakan jenis deskriptif kualitatif. Tujuannya adalah mengungkap fakta, keadaan, fenomena, variabel dan keadaan yang terjadi saat penelitian berjalan dan menyuguhkan apa adanya. Penelitian deskriptif adalah suatu penelitian yang dilakukan dengan tujuan utama untuk memberikan gambaran atau deskripsi tentang suatu keadaan secara objektif.Menurut Sugiyono (2005:21) menyatakan bahwa "metode deskriptif adalah suatu metode yang digunakan untuk menggambarkan atau menganalisis suatu hasil penelitian tetapi tidak digunakan untuk membuat kesimpulan yang lebih luas". Subjek penelitian adalah sumber utama data penelitian, yaitu yang memiliki data mengenai variabel-variabel atau permasalahan-permasalahan yang diteliti.Dikalangan peneliti kualitatif, istilah responden atau subjek penelitian disebut dengan informan, yaitu orang yang memberi informasi tentang data yang diinginkan peneliti berkaitan dengan penelitian yang sedang dilaksanakannya. Subjek penelitian terdiri dariKepala Dinas Kerja dan Pegawai.Teknik pengumpulan data ynag digunakan teknik wawancara, observasi, dan dokumentasi.Lokasi penelitian ini dilaksanakan pada Kantor Kantor Dinas Tenaga Kerja KabupatenMelawi.

\section{HASIL PENELITIAN DAN PEMBAHASAN}

Dinas Tenaga Kerja adalah bagian dari satuan kerja perangkat daerah yang mempunyai tugas pokok melaksanakan penyusunan dan pelaksanaan daerah di bidang Tenaga Kerja.Penyelenggaraan pemerintahan daerah berdasarkan pada prinsip otonomi yang luas, nyata dan bertanggungjawab. Tujuan dari penerapan otonomi tersebut adalah untuk memberdayakan potensi asli daerah, dalam hal ini menggali lebih 
banyak dan secara bertanggungjawab potensi potensial yang dimiliki daerah demi sebesarbesarnya kemakmuran masyarakat serta menumbuhkan iklim yang positif dan kondusif bagi keterlibatan masyarakat dalam proses pembangunan.Visi Dinas Tenaga Kerja Kabupaten
Melawi Tahun 2016-2021 dianggap relevan dengan visi Kabupaten Melawi Tahun 2016-2021, “Terwujudnya penyel enggaraan

Ketenagakerjaan, Ketransmigrasian dan Perindustrian yang baik".

Berdasarkan visi tersebut diatas maka Dinas Tenaga Kerja Kabupaten Melawi dalam melaksanakan tugas pokok dan fungsinya didukung oleh sumberdaya aparatur. Sebagaimana pada tabel yakni, sebagai berikut :

Tabel.1.Jumlah Pegawai Negeri Sipil Dinas Tenaga Kerja Kab. Melawi 2020

\begin{tabular}{|l|l|c|c|}
\hline No & Jenis Kelamin & Jumlah & Persen (\%) \\
\hline 1 & Laki-Laki & 13 & 59,09 \\
\hline 2 & Perempuan & 9 & 40,91 \\
\hline \multicolumn{2}{|c|}{ Jumlah } & 22 & 100 \\
\hline
\end{tabular}

Sumber: Dinas Tenaga Kerja Kabupaten Melawi 2020

Berdasarkan table di atas menunjukkan bahwa jumlah Pegawai Negeri Sipil (PNS) yang bekerja di Dinas Tenaga Kerja Kabupaten Melawi di dominasi oleh PNS laki-laki yang berjumlah 13 orang $(59,09 \%)$ dan pegawai PNS perempuan berjumlah 9 orang $(40,91 \%)$. Artinya bahwa dominasi pegawai PNS laki-laki secara psikologis

mampu bekerja secara maksimal.Oleh karena itu, dengan perbandingan pegawai ini maka tentunya dapat meningkatkan kinerja Dinas Tenaga Kerja Kabupaten Melawi. Berdasarkan dari jumlah pegawai yang ada maka dapat dilihat tingkat pendidikan pegawai sebagai berikut :

Tabel 2.Komposisi Jumlah Pegawai PNS Menurut Tingkat Pendidikan Tahun 2020

\begin{tabular}{|c|l|c|c|}
\hline No & \multicolumn{1}{|c|}{ Pendidikan } & Jumlah & Persen (\%) \\
\hline 1 & Magister (S2) & 3 & 13,64 \\
\hline 2 & Sarjana (S1) & 13 & 59,09 \\
\hline 3 & Diploma / DIII & 2 & 9,09 \\
\hline 3 & SMA/SMU & 4 & 18,18 \\
\hline \multicolumn{2}{|c|}{ Jumlah } & 22 & 100 \\
\hline
\end{tabular}

Sumber : Dinas Tenaga Kerja Kabupaten Melawi 2020

Tabel 2 menunjukkan bahwa tingkat pendidikan di dominasi oleh lulusan sarjana (S1) berjumlah 13 orang $(59,09)$. Sementara untuk Magister (S2) berjumlah 3 orang $(13,64 \%)$, Diploma 2 orang $(9,09 \%)$ dan tamatan SMA/SMU berjumlah 4 orang $(18,18 \%)$. Berdasarkan dari jumlah lulusan pendidikanmenunjukkan bahwa pegawai PNS Dinas Tenaga Kerja Kabupaten Melawi secara tingkat pendidikan sudah baik. Tingkat pendidikan sangat berpengaruh pada kinerja Dinas Tenaga Kerja Kabupaten Melawi.Oleh sebab itu, pendidikan menjadi modal penting bagi sumberdaya pegawai terutama yang berhubungan dengan kualitas sumberdaya aparatur. Sehingga dengan tingkat pendidikan yang ada tentunya dapat meningkatkan kinerja dinas tenaga kerja terutama dalam rangka pelayanan kepada masyarakat.
Observasi penulis bahwa untuk pegawai tenaga kontrak daerah pada Dinas Tenaga Kerja Kabupaten Melawi dengan jumlah 13 orang.Dengan penambahan tenaga kontrak ini mendukung kinerja Dinas Tenaga Kerja.Oleh karena itu, jumlah pegawai disesuaikan dengan kebutuhan serta kompetensi pegawai dalam melaksanakan tugasnya.Hal ini juga sangat berpengaruh dalam anggaran atau gaji yang diberikan oleh Pemerintah harus Daerah dan menjadi beban anggaran daerah. Berkaitan dengan kompetensi dan pendidikan tenaga kontrak daerah dari data yang diperoleh yang lulusan SMA berjumlah 6 orang, sarjana/S1 berjumlah 6 orang dan Magister/S2 berjumlah 1 orang. Dari data tersebut menunjukkan bahwa tingkat pendidikan tenaga / pegawai kontrak sangat baik hal ini tentunya dalam menunjang kinerja organisasi Dinas Tenaga Kerja Kabupaten Melawi. 
Berdasarkan Peraturan Bupati Kabupaten Melawi Nomor 45 Tahun 2016 tentang Kedudukan, Susunan Organisasi, Tugas Pokok, dan Fungsi Serta Tata Kerja Dinas Tenaga Kerja Kabupaten Melawi. Pasal 3 menyatakan Dinas Tenaga Kerja mempunyai tugas membantu Bupati melaksanakan urusan pemerintah yang menjadi kewenangan daerah dan tugas pembantuan yang diberikan kabupaten.

Dinas Tenaga Kerja dalam melaksanakan tugas dan fungsinya proses untuk mengubah sikap, perilaku, pengetahuan dan keterampilan bagi pegawai melalui pembentukan perilaku dan sikap kerja yang diharapkan dapat memberi kontribusi pada peningkatan produktivitas, efektitas dan efisiensi organisasi. Hal ini menjadi penting dalam membangun komitmen dan kerjasama pegawai dalam meningkatkan kinerja dinas. Pencapaian tujuan organisasi membutuhkan kerja keras dan tanggung jawab dari semua anggota organisasi untuk pencapaian visi dan misi organisasi tersebut. Tugas dan tanggung jawab bagi aparatur sipil negara (PNS) adalah memberikan pengabdian dan pelayanan kepada masyarakat.

Lingkungan organisasi dapat menciptakan kondisi dan sikap kerja pegawai yang dapat mendukung kerja-kerja organisasi dinas yang mampu menjamin rasa aman yang tercipta pada lingkungan kerja organisasi dinas. Pencapaian kinerja harus sesuai dengan target yang berkualitas, kuantitas dan waktu. Sebagaimana kinerja dinas tenaga kerja adalah kemampuan pegawai dalam menyelesaikan tugas-tugas yang dikerjakan pegawai. Sejalan dengan itu, kinerja dinas tenaga kerja mengacu kepada teori tiga komponen besar dari kinerja, yaitu kinerja tugas, kinerja keanggotaan, dan kinerja kontra produktif. Kinerja tugas merupakan penyelesaian penyelesaian tugastugas, dan tanggung jawab seperti petugas memberikan informasi kepada masyarakat dalam hal pelayanan administrasi bantuan sosial.

Pelayanan telah dilaksanakan dengan optimal dan secara terbuka artinya tidak ada diskriminasi terhadap warga masyarakat dalam menanyakan informasi kerja dan pelatihan ataupun pelayanan administrasi kartu pencari kerja. Pemberian pelayanan dengan mengacu kepada sikap para pegawai yang ramah dan bertanggung jawab sebagai bentuk komitmen akan pelayanan prima bagi masyarakat. Pemberian pelayanan yang diberikan oleh pegawai aparatur sipil Negara dengan sungguh-sungguh tanpa melihat latar belakang siapa yang dilayani. Artinya bahwa pelayanan tetap difokuskan pada kebutuhan dan kepentingan masyarakat sebagaimana prinsipprinsip pemerintahan yang baik, yakni akuntabilitas, keterbukaan dan tidak diskriminasi.

Sikap kerja yang ditunjukkan oleh pegawai Dinas Tenaga Kerja dalam melaksanakan tugas dan tanggung jawabnya tetap mengikuti prosedur yang ada. Disisi lain ada aturan-aturan atau kebijakan yang harus diikuti dalam melayani masyarakat. Berkaitan dengan prosedur dalam pelayanan tentunya tetap mengikuti yang sudah ada sehingga hal ini akan menghasilkan pemberian pelayanan yang baik. Prosedur ini diikuti dengan sikap para pegawai yang bertangung jawab, jujur dan ramah yang merupakan prinsip dalam pelayanan prima. Dengan sikap kerja tersebut tentunya akan menjadi modal serta ukuran bagi Dinas Tenaga Kerja untuk memperbaiki dan meningkatkan kinerja organisasi.

Pencapaian hasil kerja yang efektif adalah sebagai gambaran dari apa yang sudah dikerjakan atau dilakukan oleh para pegawai dengan maksud untuk mencapai tujuan yang diharapkan. Oleh karena itu, bentuk kinerja yang diinginkan dari organisasi harus mampu memberikan motivasi bagi pegawai aparatur sipil Negara dan pengembangan pengetahuan pegawai, pengembangan kerjasama dan memiliki komitmen. Keberhasilan suatu organisasi pemerintah dalam mencapai tujuan sangat ditentukan oleh mutu profesionalitas pegawai, disiplin dalam bekerja, kesungguhan yang dilakukan oleh pegawai agar mampu mencapai tujuan dan kinerja organisasi. Hal ini sejalan dengan faktor yang mempengaruhi kinerja antara lain, kemampuan, motivasi, dukungan yang yang diterima, keberadaan pekerjaan yang dilakukan, dan hubungan pegawai dengan organisasi. Beberapa faktor inilah sebagai evaluasi bagi organisasi dalam mencapai kinerja yang efektif.

Aparatur pemerintahan dalam mencapai kinerja organisasi harus mencakup unsur-unsur ketaatan, kesetiaan, kesungguhan dalam menjalankan tugas dan kesanggupan berkorban, dalam arti mengorbankan kepentingan pribadi dan golongannya untuk kepentingan negara dan masyarakat.Karena hakekat pelayanan yang responsif adalah pelayanan yang mampu merespon dan mengenali kebutuhan serta kepentingan yang diperlukan oleh masyarakat. Oleh karena itu, pelayanan yang responsif artinya pelayanan dengan baik dan optimal harus ditunjang dengan sarana dan prasarana yang ada baik dari sisi sumberdaya manusia aparatur dan sumberdaya fisik seperti ruang tunggu, loket, printer, dan komputer. Dalam hal pemberian pelayanan harus diikuti dengan 
sumberdaya manusia yang bertanggung jawab dan fasilitas sebagai sumber pendukung agar pemberian pelayanan yang diberikan kepada masyarakat lebih efektif.

Pengembangan pegawai merupakan kegiatan dalam rangka mempersiapkan para pegawai untuk kemajuan dikemudian hari, kegiatan pengembangan juga menjamin pegawai memenuhi syarat untuk posisi yangdicitacitakan.Pengembangan pegawai pada dasarnya bertujuan untuk memastikan dan memelihara kemampuan pegawai sehingga memenuhi kualifikasi yang diprasyaratkan sehingga selaras dengan tujuan organisasi agar dapat tercapai sebagaimana yang direncanakan. Ada dua aspek kegiatan penting yang tidak dapat dipisahkan satu sama lain, yakni kegiatan pelatihan dan kegiatan pengembangan sumberdaya manusia itu sendiri. Kedua kegiatan tersebut dimaksudkan untuk mengembangkan kompetensi yang dimiliki pegawai agar dapat digunakan secara efektif. Kegiatan pelatihan dipandang sebagai awal pengembangan pegawai yaitu dengan diadakannya proses orientasi yang kemudian dilanjutkan secara berkelanjutan selama pegawai tersebut berada di dalam organisasi. Artinya bahwa sasaran dari dilaksanakannya pendidikan dan latihan adalah untuk memantapkan pegawai dalam rangka bagaimana menyiapkan diri untuk bekerja dengan optimal.

Pendidikan dan pelatihan (diklat) sangat penting untuk mencapai tujuan organisasi terutama kepada pegawai yang bekerja sesuai dengan tugas dan tanggung jawabnya. Oleh karena itu, diklat yang baik perlu diikuti dengan komitmen, disiplin serta tanggung jawab yang tinggi sehingga akan mendorong peningkatan kinerja dan perubahan sikap, dan perilaku aparatur sipil Negara yang lebih baik. Pertimbangan instansi dalam melaksanakan diklat untuk para pegawainya adalah pembinaan dan pengembangan karir pegawai yang bersangkutan, kepentingan, promosi, tersedianya anggaran dan syarat-syarat pegawai yang mengikuti diklat.Untuk pemilihan pegawai yang diikutsertakan dalam diklat didasarkan pada kebutuhan organisasi, alasan peningkatan kinerja, kemampuan dan keterampilan pegawai.

Dinas Tenaga Kerja Kabupaten Melawi sampai dengan tahun 2019 jumlah Pegawai ASN yang sudah mengikuti Diklat berjumlah 3 orang terdiri dariDiklatpim II dan III. Sementara yang belum mengikuti Diklatpim 11 orang yakni Diklatpim III dan IV. Hasil menunjukkan bahwa Diklat yang sudah diikuti oleh pegawai aparatur sipil Negara sebagai bentuk komitmen dan tanggung jawab Dinas Tenaga Kerja dan Pegawai dalam meningkatkan dan menambah pemahaman akan pendidikan dan pengetahuan sehingga mampu bekerja sesuai dengan tugas dan tanggung jawabnya.

Menurut Undang-Undang Nomor 5 Tahun 2014 tentang Aparatur Sipil Negara mengatur tentang pengembangan kompetensi pegawai melalui pendidikan dan pelatihan.Pasal 70 disebutkan bahwa setiap pegawai Aparatur Sipil Negara (ASN) memiliki hak dan kesempatan untuk mengembangkan kompetensi tersebut diantaranya melalui pendidikan dan pelatihan. Diklat aparatur ASN ini sebagai pengembangan kompetensi pegawai yang merupakan tanggung jawab Dinas Tenaga Kerja untuk mengusulkan pegawai untuk mengikuti diklat. Dengan diklat yang diikuti para pegawai dapat menambah wawasan pengetahuan dan ketrampilan agar memperbaiki kualitas, kapasitas ASN sehingga dapat meningkatkan kinerja ASN yang optimal di DinasTenaga Kerja Kabupaten Melawi.

Berdasarkan analisis hasil penelitian ini menunjukkan bahwa kinerja dijadikan sebagai ukuran dalam mencapai hasil kerja yang optimal. Penilaian kinerja dibutuhkan dalam pengembangan sumberdaya manusia aparatur.Sistem penilaian kinerja harus berlandaskan pada prinsip keadilan, transparansi, tidak diskriminasi, dan semangat berkompetisi.Tujuan dan manfaat dari penilaian kinerja sebagai suatu yang bersifat evaluasi dan pengembangan, perbaikan kinerja, dan membantu diagnosis terhadap kesalahan desain pegawai.Kinerja memerlukan penilaian dalam mengetahui kelemahan dan kekurangan sejauhmana pegawai dalam menyelesaikan tugas dan tanggung jawabnya. Dengan demikian, untuk mencapai tujuan kinerja yang maksimal, sudah seharusnya instansi pemerintahan perlu mengembangkan kemampuan dan sikap kerja, budaya kerja dan disiplin pegawai mengacu kepada prinsip-prinsip tata kelola pemerintahan yan baikdalam meningkatkan kinerja Dinas Tenaga Kerja Kabupaten Melawi.

\section{KESIMPULAN DAN SARAN}

Kinerja Dinas Tenaga Kerja sudah baik yang merupakan ketercapaian dari pegawai yang mampu bekerja dengan efektif dan bertanggung jawab.Bentuk kinerja yang dilakukan dengan menunjukkan sikap kerja yang professional, melayani masyarakat yang mengurus administrasi, memberikan penyuluhan dan latihan bagi masyarakat untuk menghadapi dunia kerja.Kendala yang dihadapi adalah sebagian pegawai yang belum mengikuti diklat. Hal ini penting bagi pegawai untuk meningkatkan kualitas dan kompetensi pegawai.Kinerja sebagai ukuran evaluasi dan pengembangan dalam mendiagnosa setiap kelemahan dan kesalahan yang menghambat 
organisasi.Saran penulis dalam penelitian ini adalah sikap kerja harus dibentuk sejak pegawai diangkat menjadi aparatur sipil Negara agar pekerjaan yang dilakukan, kemampuan kerjasama pegawai, dan tanggung jawab.Dengan sikap kerja yang sudah melekat dalam diri aparatur sipil Negara tentunya dapat mendukung tercapainya kinerja organisasi Dinas Tenaga Kerja Kabupaten Melawi.

\section{DAFTAR PUSTAKA}

Abdurrahmat Fathoni, 2006. Manajemen Sumber Daya Manusia. Bandung : Rineka. Cipta.

Atong, Petrus, 2018. Pemikiran Kontemporer Analisa Administrasi dalam Perspektif Kebijakan Publik dan Komunikasi di Era Pelayanan Publik. Malang : IRDH.

HM Ismail, 2009. Etika Birokrasi dalam Perspektif Manajemen Sumberdaya Manusia.Malang : Ash-Shiddiqi Press.

Mahsun, Mohamad, 2006.Pengukuran Kinerja Sektor Publik. Yogyakarta: BPFE. Miles, Matthew B danHuberman, A Michael,1992. Analisis Data Kualitatif.Jakarta: UI Press.

Moleong, Lexy J.2002. Metodologi Penelitian Kualitatif. Bandung: Remaja Rosda Karya.
Mangkunegara, Anwar Prabu . 2007. Manajemen Sumber Daya Manusia. Bandung : Remaja Rosdakarya.

Nasucha, 2004.Reformasi Administrasi Publik. Jakarta :Grasindo.

Umam, Khaerul, 2010. Perilaku Organisasi. Bandung : Pustaka Setia.

Sedarmayanti, 2009.Reformasi Administrasi Publik, Reformasi Birokrasi, dan Kepemimpinan Depan (Mewujudkan Pelayanan Prima dan Kepemerintahan yang Baik).Bandung : Refika Aditama.

Sumarsono, 2003.Ekonomi Manajemen Sumberdaya Manusia dan Ketenagakerjaan.Yogyakarta : Graha Ilmu.

Sugiyono, 2005.Metode Penelitian Administrasi.Bandung : Alfabeta.

\section{Peraturan Perundang-Undangan}

Undang-Undang Nomor 5 Tahun 2014 Tentang Aparatur Sipil Negara.

Peraturan Pemerintah Nomor 53 Tahun 2010 Tentang Disiplin Pegawai Negeri Sipil.

Peraturan Pemerintah Nomor 42 Tahun 2004 Tentang Pembinaan Jiwa Korps dan Kode Etik PNS 